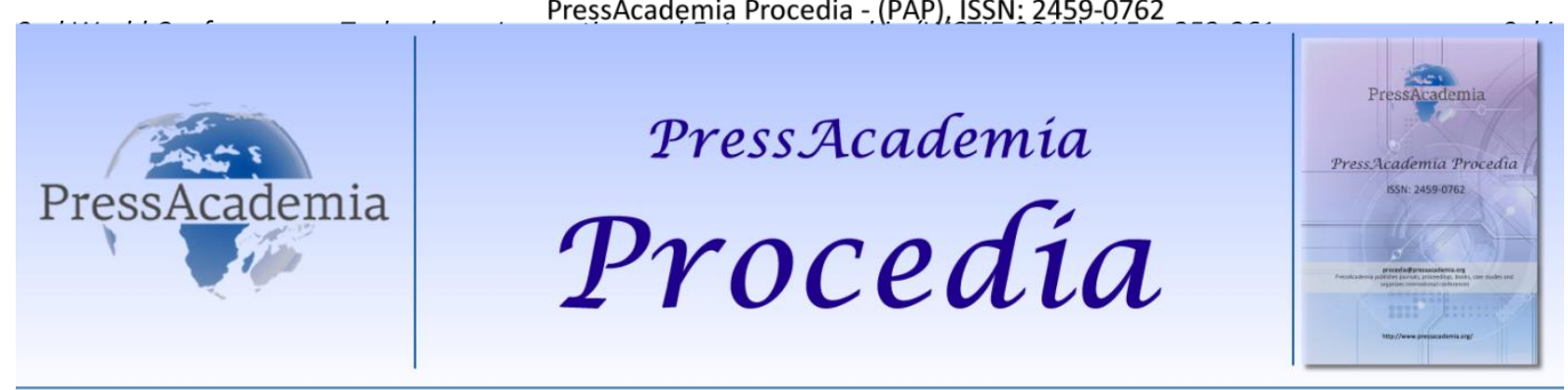

2nd World Conference on Technology, Innovation and Entrepreneurship

May 12-14, 2017, Istanbul, Turkey. Edited by Sefer Şener

\title{
TURKEY ON THE PATH OF ESTABLISHING KNOWLEDGE ECONOMY: INNOVATION, ICTS AND EDUCATION
}

\author{
DOI: 10.17261/Pressacademia.2017.597
}

PAP-WCTIE-V.5-2017(35)-p.253-261

\section{Burcu Sakiz ${ }^{1}$}

${ }^{1}$ Istanbul Aydin University, burcubaydar78@gmail.com

\begin{abstract}
Knowledge-based economy is re-defining enterprises, re-formatting working styles, empowering individuals and re-shaping the links between education and business tasks in today's globalized world. Emerged communication and information technologies especially invented in six decades ago is still changing the nature of business and the economy dramatically. It is obvious that transition to knowledge-intensive business models become popular since late 1950s. Also it is clear that advent of the knowledge economy shapes and changes the rules for enterprises that organize their activities in the global market places. Additionally intellectual capabilities become more important than physical inputs which was very important for the first machine age. The application of knowledge is one of the main sources of growth in the global economy and it becomes the strategic factor for the success. Having sufficient national production, sustainable growth, strong economy and modern technologies to create a welfare society is crucial for any modern nation. This study presents the concept of the knowledge economy and it's framework in this respect. Developed by World Bank "Knowledge Assessment Methodology" is one of the important methodologies in order to measure the progress of countries towards having a knowledge based economy. It has 4 pillars including 83 structural and qualitative variables and 12 knowledge indicators. World Bank's four Knowledge Economy pillars are economic and institutional regime, education, innovation, and Information and Communication Technologies (ICTs) developed for countries to do fundamental assessment of countries' readiness for the knowledge economy and help them the transition to a Knowledge-based Economy. Also in this paper the analysis of knowledge economy for Turkey especially the role of innovation, ICTs and education pillars are examined.
\end{abstract}

Keywords: Knowledge economy, knowledge assesment methodology, innovation, ICT, education.

\section{INTRODUCTION}

In the knowledge society that we are in, service/knowledge technologies have come into prominence. Knowledge became most valuable asset when it is compared to land, physical labor, machines and factories. Thomas A. (1997) asserts that wealth is production of knowledge in today's world. According to him, "knowledge and intellectual capital which is organized knowledge that can be used to produce wealth is becoming corporate America's most valuable asset and can be its sharpest competitive weapon. The challenge is to find what you have-and use it". He demonstrated how knowledge has become the most important factor in economic life instead of natural resources, machinery, or financial capital. In the knowledge society that we are in service/knowledge technologies have come into prominence. Use of computers and communication technologies especially in academic and business world and in personal life has increased year by year. Therefore major changes have been observed in social and economic structure especially in developed countries. Knowledge Society has witnessed to alteration and transformation of populations. Knowledge brings speed and effectiveness for production and it plays the key role for the world's economy. In the 21st century, the knowledge-based economy has become the major trend for international societies (George, et al., 2008).

The change towards a knowledge-based economy is happening on a global scale, a transformation is taking place in all industrialized economies and many developing economies are also aspiring to reach this target. Many studies in the literature focus on the knowledge-based economy. Gür's (2001) study about constructing a new framework which is to be utilised for the assessment of possible strategies which can be applied during the transition to a knowledge-based economy. He developed mixed integer programming model in order to determine the required levels of human resources and information and communications technology investments for given levels of R\&D investment of the country that 
determines most significant characteristic of the phenomenon. The results indicate that Turkish government should increase R\&D to considerable levels in order to trigger the transition to a knowledge-based economy. Second important finding is transformation towards a knowledge-based economy with an inefficient innovation system may require considerable amounts of additional resources compared to transforming with a more efficient system.

Umut's (2001) study about constructing a new framework that utilizes assessment of possible strategies can be applied during the transition to a knowledge based economy. A mixed integer programming model developed by him to determine the required levels of human resources and information and communications technology investments for given levels of R\&D investment of the country. Results indicated Turkish government should increase R\&D to considerable levels in order to trigger the transition to a knowledge-based economy

Salduz (2005) studied that examine Turkey's position as a candidate country in adaptation to the Lisbon Strategy. She gives general information concerning knowledge economy and EU's activities aiming to reach Lisbon strategy and EU-Turkey comparison with using knowledge economy indicators also she examined Turkey's adaptation process. Study reveals that Turkish economy has many disadvantages both for knowledge production and using information technologies and economy needs reconstruction to close this gap and also for knowledge economy that reconstruction requires renovations in science and technology policies, education policy and industrial policy.

Arıkan (2008) examines the dynamics of the innovationy with 122 Turkish firms from a wide variety of sectors, through exploring the characteristics of organizations in terms of their openness to innovations. Relating this innovative culture both to the systems organizations utilize to enhance innovations and to the actual innovations implemented in his thesis. The results show that innovation leads to better business performance. An organization's market orientation, learning orientation, and entrepreneuiral orientation lead to more openness to innovations.

Tuncay (2008) studied the place and importance of knowledge economy in the economic growth process. an augmented Cobb-Douglas production function, which is an approach based on neo-classical theory is used in investigating the effect of knowledge on the economic growth of Turkey and thus the direction and size of the relation between investments in knowledge communication technology and economic growth in Turkey during years between 1980 to 2006. The results showed that the investments in communication technology knowledge have a positive effect on economic growth for Turkey.

Senem (2011) studied discussions on clarifying of relationship with knowledge economy and growth and productivity paradox by linking the presence of threshold effects. "being over of a specific level of some factors that countries have, leads to differences in the relationship with knowledge economy and growth" is the hypothesis. The panel data set is analyzed consisting of 39 countries with different level of development with fixed effects method for years 1995, 2000, $2007,2008,2009$. In growth model which is per capita income is dependent variable; Knowledge Economy Index (KEI), R\&D, capital, employment ratio are explanatory variables examined for the threshold effects for KEI and R\&D variables as well as the numerical and statistical chancing of KEI coefficient is examined for indexes containing human capital, technological knowledge and innovation capacity, information and communication technologies (ICT) .

Memişoglu (2012) studied major factors of knowledge-based economies between years 2000-2010 based on World Bank Knowledge Assessment Framework, on economic performance indicators such as Gross Domestic Product(GDP), GDP per capita and economic growth rate in Brazil, Russia, India, China, South Africa and Turkey (BRICST). Secondary education and ICT infrastructure are found to be important infrastructure factors affect GDP per capita positively for BRICST countries. Country's ability to innovate, benefit from ICT and enhance economic performance can be affected by accumulation of educated people in Research and Development. Also personnel number of R\&D which is an indicator for innovation potential has positive influence on the GDP. The major things affect economic performance found as ICT infrastructure expansion together with educated R\&D personnel in the BRICST countries.

Vuslat(2014) studied reviews institutional transition in particular universities around the world by means of knowledgebased economy. The aim of her study is to comprehend the institutional transition by means of knowledge-based economy in general and transition of universities is investigated deeply among institutions as an important part for innovation and knowledge in 4 Turkish Universities as Istanbul Technical University, Boğaziçi University, Sabancı University, and Istanbul Bilgi University. Also some universities from the world are examined about their management, productivity, and academic change.

Işık (2012) studied effects of R\&D, Innovation, Patent, Information Technologies for Turkey in years between 1990-2010. The competitive advantage factors in knowledge economies are analyzed by various methods. As a result of theoretical and empirical analyses, it is determined that the factors of competitive advantage in knowledge economies, contribute to the economic growth and the development of our country's position in the world in respect to knowledge economy. 


\section{KNOWLEDGE BASED ECONOMY}

The knowledge economy can be defined as "in the use of knowledge to generate tangible and intangible values. Technology helps to transform a part of human knowledge to machines and tools. This knowledge could be used by decision support systems and generate economic values in various fields". Besides, emerging technologies and changes in the production structure have changed the demand structure significantly. (Sadık, 2000). As Charles Leadbeater (2000) states, more of the value of manufactured products will come from the software and intelligence that they embody, and more of what we consume will be in the form of services in the new economy. The knowledge across all sectors, content of products and processes is ascending. Everything is getting smarter from computers and photocopiers to cars and corn.

It is emerged as a result of intensive knowledge in economic activities, globalization of economic activities and improvements in information and communication Technologies (ICTs). OECD(Organisation for Economic Cooperation and Development) defines knowledge economy as: "Economy in which knowledge is being used in distribution and production."(OECD, 1996). According to OECD Knowledge-Based Economy Report (1996), the new driver of productivity and economic growth was defined as knowledge. The new global economy is very distinctive in terms of its strategies of flexible production organized around principles of knowledge based economy that knowledge is accepted as the main drive of the economic growth.

Susan(2005) sets the essence of the knowledge economy as:

- the balance between knowledge and resources (labor and capital) has shifted toward knowledge;

- $\quad$ securing long term economic growth will be much more dependent on knowledge;

- $\quad$ education will play a critical role in economic growth;

- $\quad$ education systems will need to respond in new ways to the demands of knowledge economy.

Economic incentives and institutional regime, policies and information and communications technologies (ICTs) are pillars of the knowledge-based economy. Access to networking is essential in acquiring and disseminating knowledge and the Internet is one of the key drivers of ICT, resulting in new approaches to doing things. We are witness to arising of new important definitions and drivers for economic performance. Such as information society with increasing communication and computer networks, learning economy with the need of workers to acquire a range of skills and to steady adapt these skills, and national innovation systems with the raising importance of knowledge and technology diffusion requires better understanding of knowledge networks are defined in knowledge-based economy (OECD, 1996). There has been a knowledge explosion because of new inventions especially in the last five decades by growth in technological researches and in the usage of the technical tools and equipments.

Knowledge-based economy also leads collaboration opportunities for information and communication technologies to conceive high qualified products with low costs (European Commission, 2001). Economic model in which knowledge comes into prominence, drives existing business processes and way of doing works to be more qualified (Oytun, 2013). As a matter of fact, any kind of production is knowledge-based. Economy's main elements which are production, consumption, distribution and their relationships also new market structure have been restructured based on knowledge. Consumers began taking goods and services faster, without being limited by time and location. Researchers can analyze consumer behaviors better and more accurate with more datum in digital environments. Barriers to market entry and exit reduce and information becomes a function of competition (Oğuz, 2005). Since barriers have been removed, producing innovative gods and services have become a must. The economic effects of physical distances, geographical differences and the cost of access to information have been decreased result of using ICTs. Moreover, new startups costs are declining and the advantage to compete in new markets is increasing. Despite financial capital has accepted as a formerly scarce resource, in today's world qualified human resources become scarce resources (Kamil, 2007).

Since knowledge has no fixed capacity, shows more rapid change in that sense and tends to be obsolete in a short period of time, it is difficult to calculate knowledge's market value. Additionally, knowledge is difficult component to quantify. The first attempt for the assesment of knowledge and development of a framework to interpretation of data related to science, information, technology, communication and innovation has been made by OECD. The OECD report notes that $-O E C D$ countries continue to evidence a shift from industrial to post-industrial knowledge-based economies. Here productivity and growth are largely determined by the rate of technical progress and the accumulation of knowledge. Of key importance are networks or systems which can efficiently distribute knowledge and information. Learning on the part of individuals and firms is crucial for realizing the productivity potential of new technologies and longer-term economic growth. Many other institutions like World Bank, Eurostat Eurostat, UNESCO, International Telecommunication Union and United Nations have introduced a range of indicators in order to analyze country's potential for knowledge and knowledge based economy. They have been built several indexes. Well-known institutions which develop these indexes are The World Bank, Harvard 
University International Development Center, McConnell International, The Economist Intelligent Unit, UNCTAD, The United Nations Development Program, World Economic Forum and The Mosaic Group (Leila, et.al, 2007).

\subsection{Pillars of Knowledge Economy}

In 1999 the World Bank developed Knowledge Assessment Methodology (KAM) which is a method aims to show opportunities to countries and identify problems may them face towards transition to knowledge economy. KAM is designed to supply basic assessment of countries' readiness for the knowledge economy, and identifies sectors or specific areas where policymakers may need to focus more attention or future investments. It has an online interactive tool that produces the Knowledge Economy Index (KEI)-an aggregate index representing a country's or region's overall preparedness to compete in the Knowledge Economy (KE). Knowledge Economy Index indicates a country's or a region's overall level of development in terms of knowledge economy. KAM has 69 structural \& qualitative variables on 4 pillars and normalized from 0 (worst) to 10 (best) for 100 countries. The unique strength of the KAM lies in its cross-sectoral approach that allows a holistic view of the wide spectrum of factors relevant to the knowledge economy. These factors are briefly summed up as follows: Information and Communication Technologies: Appropriate business environment that the knowledge economy can be developed in; R\&D and Innovation; Education

\section{ON THE PATH OF ESTABLISHING KNOWLEDGE ECONOMY AND TURKEY}

\subsection{Turkey and World Knowledge Economy Comparisons}

The underlying reasons behind differences in countries' long-term growth performances are grouped under four main headings such as investment (fixed capital, and information and communication technology sector), non-formal education, innovation and structural change. According to our study, relationship between the Knowledge Economy Index (KEI) and GDP examined and results are positive. According to the our regression test depicted below, the correlation between KEI and economical performance is about $85 \%$. GDP and KEI relations, Knowledge Economy Index of Turkey pillars figures and KEI table are given below.

Figure 1: GDP per Capita \& KEI Relation

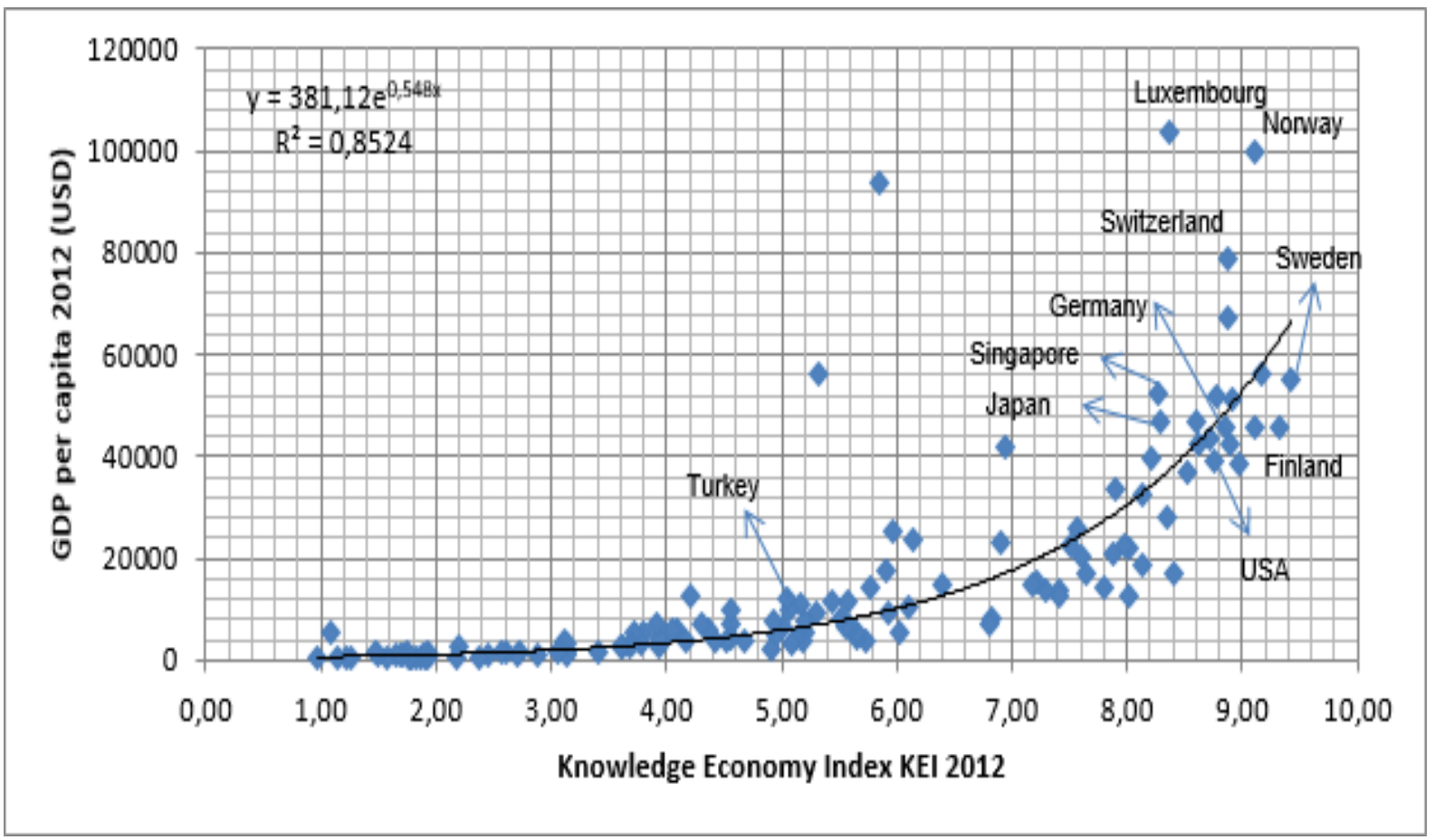


Figure 2: Turkey and World KEI

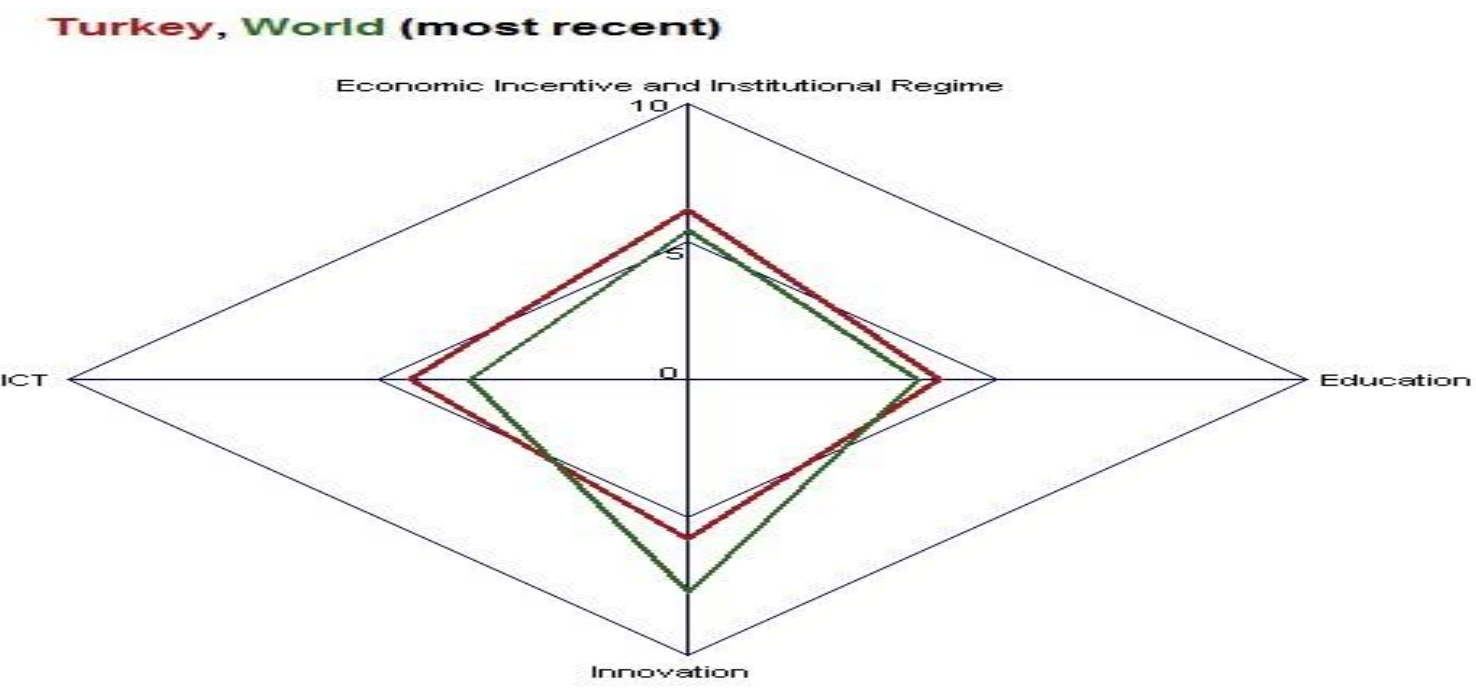

KAM 2012

According to "Informatics for Breakthrough, Turkey for Economics Information and Communication Technology SectorBreakthrough Strategy 2023" report, while Turkey's competitiveness in the information and communication sector (ICS) is poor, some other developing countries' competitiveness is high. While South Korea, Singapore and Brazil don't show any alteration, in China and India there has been a significant increase in competitiveness in the last three years. ICS's productivity in Turkey is four times of total private sector productivity. Despite this importance, it is seen that contribution that ICSs should make in increasing productivity in Turkey hasn't occurred. A conclusion shouldn't be drawn like there is no affect of ICS in increase in productivity. The underlying reason of this is ICS' small share in whole economy and this small is decreased rather than increase in the examined period. Taking into account all variables of Turkey's KI and KEI ranks, results are: fixed capital investment and information and communication sector investments are not enough; Research \& Development expenditures fall behind the fast developing countries, but increase in production efficiency by innovating could be achieved; develop the educational level of human capital not achieved, tendency to high-tech products in the structure of production remained limited. In below table knowledge related indexes are given for World and Turkey.

Table 1: Turkey and World knowledge related indexes

\begin{tabular}{|l|c|c|}
\hline Index & World & Turkey \\
\hline Knowledge Economy Index & 5,12 & 5,16 \\
\hline Knowledge Index & 5,01 & 4,81 \\
\hline Economic Incentives and Institutional Regime & 5,45 & 6,19 \\
\hline ICT & 3,58 & 4,5 \\
\hline Innovation & 7,72 & 5,83 \\
\hline Education & 3,72 & 4,11 \\
\hline
\end{tabular}

\subsection{ICTs, Innovation and Education Pillars}

In the 21st century, we are in the midst of "knowledge revolution" that increased importance of education, innovations and also updated skills for sustainable economic performance and improvement. The knowledge economy is transforming the demands of the labor market in economies throughout the world. In industrial countries, where knowledge based industries are expanding rapidly, labor market demands are changing accordingly (World Bank, 2003: 1).

ICT includes a dynamic information infrastructure-ranging from radio to the internet-is required to facilitate the effective communication, dissemination and processing of information. A dynamic information infrastructure is needed to facilitate the effective communication, dissemination, and processing of information. information infrastructure that facilitates the communication, dissemination, and processing of information and technology. The increased flow of information and 
knowledge worldwide reduces transactions costs, leading to greater communication, productivity and output. Today's global competitive environment, becoming successful and increasing the productivity will be possible not only by structureprocess and technological changes but also by using knowledge and utilizing of ICTs(Information and Communication Technologies) especially teaching and developing of high quality human sources and by preparing them for the new concepts. ICTs lower the costs of various aspects of knowledge activities. How intense countries use their knowledge and ICTs and contributions do these technologies becomes very important. In this context, Turkey has been reconstructing certain processes and policies to keep pace with alterations and to be competitive benefiting from advantages of the process (Eda, 2011).

Turkey would be count as to be a young industrial country by the courtesy of policies such as protectionism and incentives. Turkey owes partial change to the law of diminishing returns. Law of diminishing returns, gives developing countries a chance to learn producing goods with high added value. However, law of increasing returns is valid in knowledge society. Thus, specialization in the production of goods with high added value and making production more efficient through knowledge are required (Sadık, 2000). According to the "Information and Communication Technologies toward 2023 Goals" report of International Investors Association, it is expected that impact of 1 unit of growth in information and communication sector will be 1.8 units of growth in whole economy. In 2011, ICT sector size at the global level has reached $\$ 4.1$ trillion. And the size of the sector in Turkey is estimated to be $\$ 30,3$ billion. Turkey's country's share in global information and communication sector remaining at $0.75 \%$ indicates the sector's growth potential. When the sub-sectors of the market in Turkey are analyzed, it is seen that the growth potential of ICT industry whose share is $0.4 \%$ in global market, is much higher. In case of reaching targeted $8 \%$ share of ICTs in \$2 billions GDP, merely to be provided contribution through total factor productivity growth is estimated to be over $\$ 71$ billion (YASED International Investors Association, 2014).

An educated and skilled population that can create and use knowledge and an effective innovation system consisting of research centers, universities, think tanks, and other organizations that can create knowledge are two drivers for development. Educated, creative and skilled people and effective national innovation system are two important factors. For innovation system, KAM uses three variables: R\&D per million population, patent applications granted by the US Patent and Trademark Office (USPTO) per million population, and scientific and technical journal articles per million population. In summary KAM's innovation pillar aims to measure country's innovation system - firms, research centers, universities, think tanks, consultants, and other organizations-must be capable of tapping the growing stock of global knowledge, assimilating and adapting it to local needs, and creating new technology.

According to Innovation Union Score Board which is used to measure innovativeness by Europe Union Commission and is compiled through 25 indicators, even Turkey displays an increasing performance since 2006; she is still between countries that categorized as low in terms of innovation. In below figure, rankings of Turkey and other countries can be seen. Also we get application data from European Patent Office to compare european countries with Turkey. Turkey still has a lot of potential to grow its performance compared to its population. Moreover according to Turkish Patent Institute's data, Turkey's patent application numbers are increasing since 20 years.

Figure 3: Innovation Union Scoreboard 2015 (European Commission).

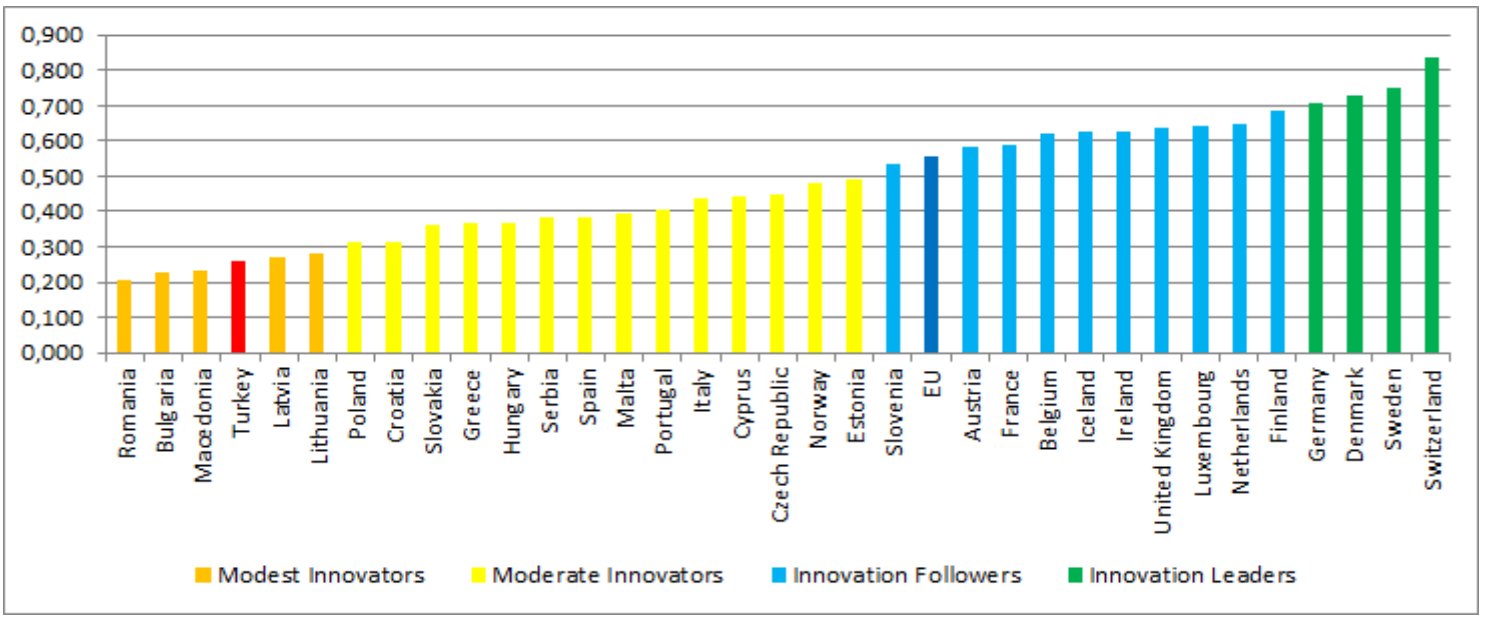


Figure 4: European Patent Office applications per mio. inhabitats

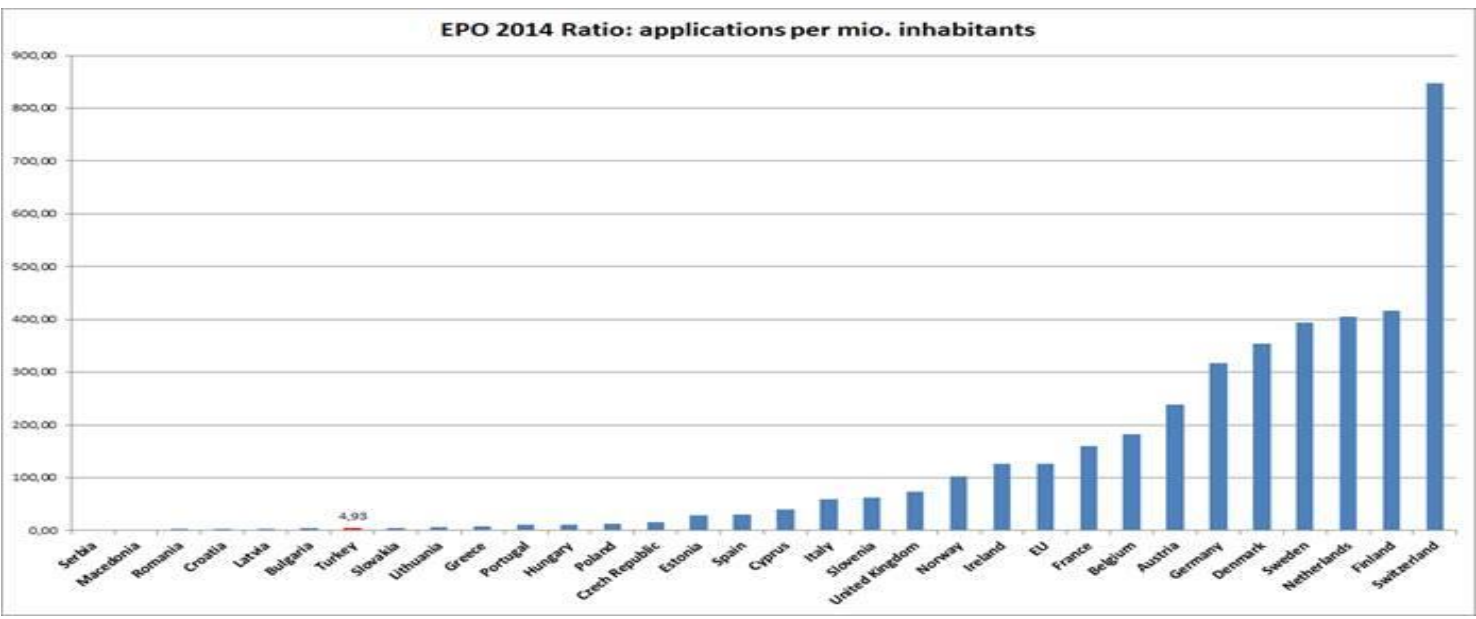

In industrial countries, where knowledge based industries are expanding rapidly, labor market demands are changing accordingly (World Bank, 2003: 1).World Bank's KAM methodology "education and skills" pillar aims to measue country's people needs education and skills that enables them to create and share, and to use it well. Education has a significant role to play that goes beyond input/ investment models to a finessed output set of specifications. For education pillar, three variables are used: the adult literacy rate (percentage of population aged 15 and above) gives a very broad stock measure of educated population, gross secondary enrollment rate and gross tertiary enrollment rates provide a flow rate. Experiences of developed countries shows that national innovation system, human development, effective education system and information-delivery technologies and business environments should affect each other satisfyingly and they should develop parallel to each other in order to have a successful knowledge economy (World Bank, 2004). Literacy rate, adult total (\% of people ages 15 and above) in Turkey was 94.92 as of 2012 and 95,5 for 2015 as an estimation.

Over the past decade, the OECD Programme for International Student Assessment, PISA, has become the world's premier yardstick for evaluating the quality, equity and efficiency of school systems. PISA evaluates education systems worldwide by testing in key subjects critical thinking in math, science, and reading to 15 year olds $(O E C D, 2012)$ It conducts research on the 65 countries that make up 90 percent of the world's economies. The OECD Directorate for Education has found that student achievement in math and science are a sound indicator for future economic health. Turkey has involved this test since 2003. As of 2015, they revealed 2012 PISA test results. According to PISA 2012 results, Turkey is ranked 42nd for maths, 41st for reading skills and 45th for science skills. Turkey had low PISA scores in 2003 and recorded an average fourpoint improvement in all three skills in 2012.

Figure 5-6-7-8-9: Student performance in maths, reading, science, problem solving means by countries

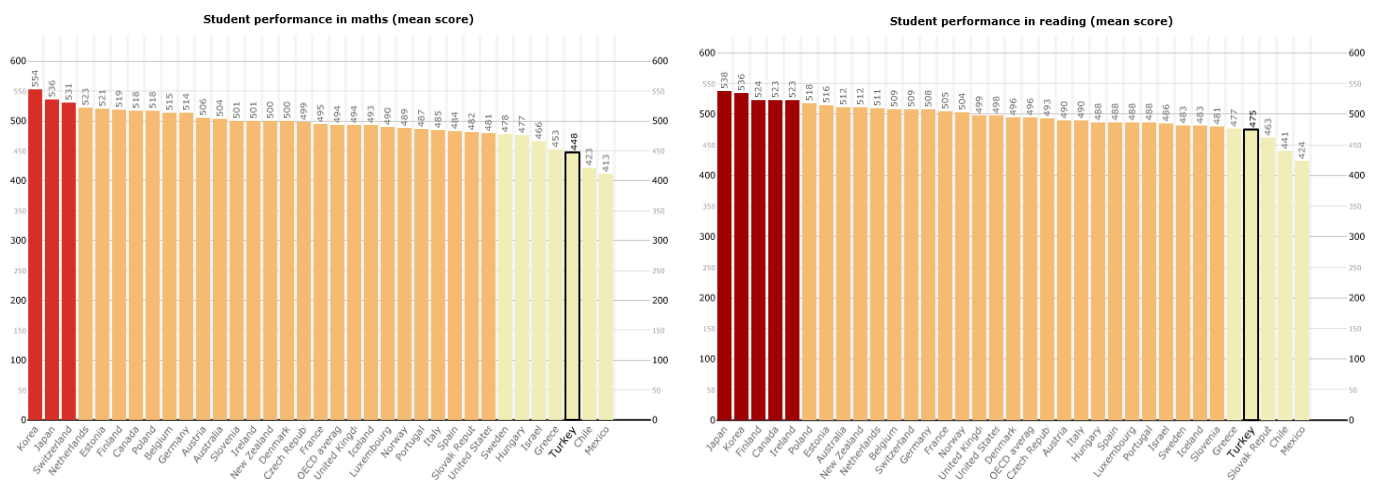



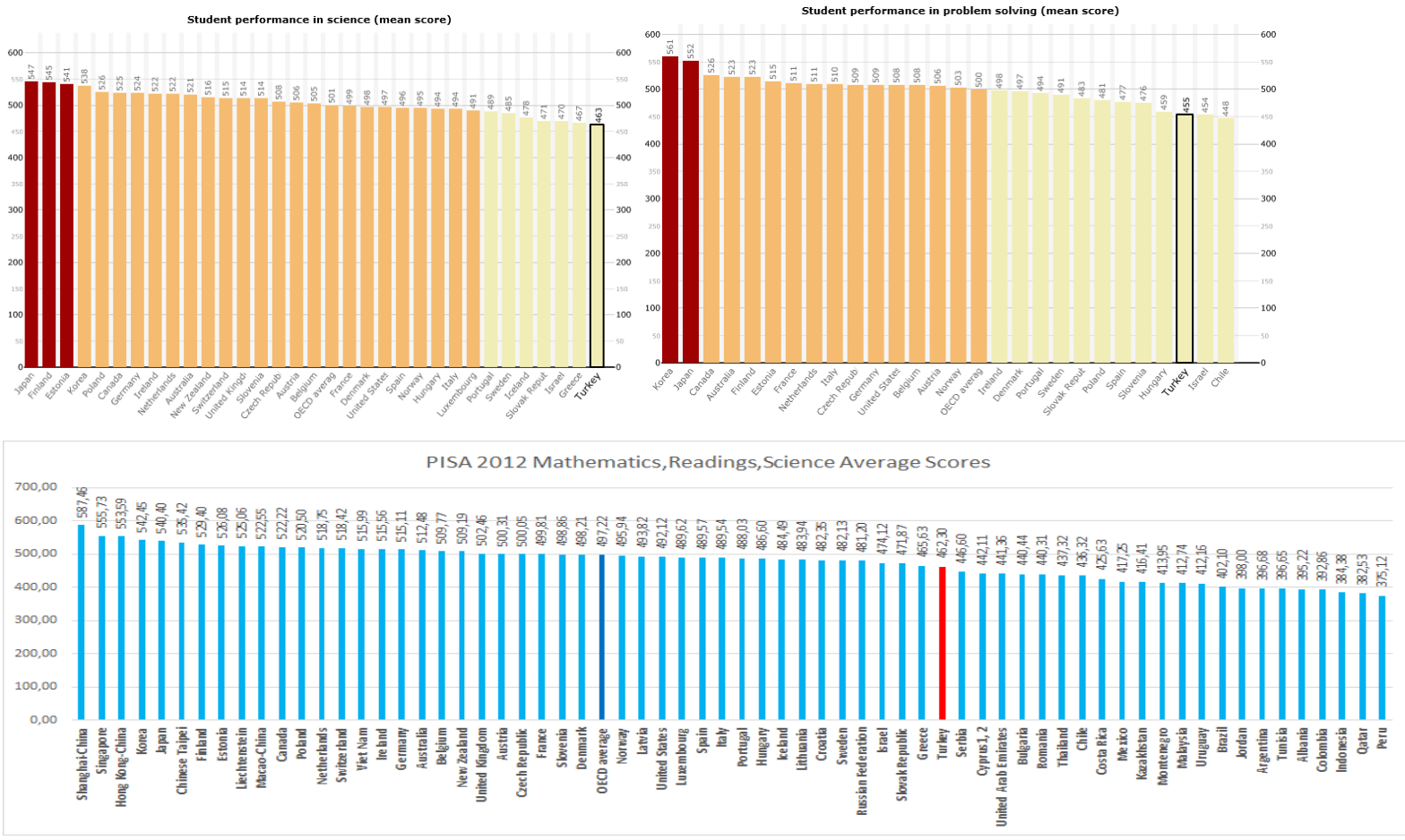

\section{CONCLUSION}

Knowledge economy relies primarily on the use of ideas rather than physical abilities and on the application of technology rather than the transformation of raw materials or the exploitation of cheap labor. It is an economy in which knowledge is created, acquired, transmitted and used more effectively by organizations, individuals, enterprises, and communities and that's why it promotes economic and social development. Knowledge economy discourse borrows heavily from work developed by a group of 1960s intellectuals, futurologists and information economists, like Peter Drucker (1969), Fritz Machlup (1962) and Daniel Bell (1973)-that industrial societies were in transition to becoming variously knowledge economies, post-capitalist and post-industrial societies. It is an economy in which knowledge is created, acquired, transmitted and used more efficiently and effectively by governments, enterprises, organizations, individuals and communities and it promotes economic and social development. In 1999 the World Bank Institute launched a project entitled "Knowledge for Development". It aims were to raise awareness among national policymakers about the powerful growth effects of knowledge and to encourage economists to combine global and local knowledge in order to accentuate comparative advantages (World Bank, 2008). According to findings, Turkey should increase investments in information and communication Technologies, also increase R\&D expenditures, increase level of productivity in production by innovations, upgrade the level of education to have required necessary qualified human resources and should be directed to high-tech products in the production structure on the path of establishing knowledge economy.

\section{REFERENCES}

Arıkan, 2008. Evaluating the dynamics of innovation in Turkey: The impact of innovation on business performance, Boğaziçi University, Business Administration, PhD Thesis, İstanbul.

Işık, 2012. The economic analysis of R\&D, innovation, patent and information technologies which influence the establishment of competitive advantage in knowledge economies: An application on Turkey's Economy, Atatürk University Social Sciences, Economics, Phd Thesis, Erzurum.

Leila, vd, 2007. "Adoption A Proper Tool For E-Readiness Assessment In Developıng Countrıes; Case Studies: Iran, Turkey And Malaysia", Journal of Knowledge Economy \& Knowledge Management Volume II Spring, s.54.

Vuslat, 2014. "The transition of institutions by means of knowledge based Economy: case of Turkish universities", ITU, Department of Urban and Regional Planning Regional Planning Programme, M.Sc. Thesis, Istanbul 
Eda, 2011. "Enformasyon Toplumu ve Bilgi Çağında Türkiye'nin Gelişim Süreci", Marmara Üniversitesi, Sosyal Bilimler Enstitüsü, İktisat Politikası Bilim Dalı, Master Thesis, İstanbul.

European Comission, 2001. The Impact of The E-Economy on European Enterprises: Economic Analysis and Policy Implications, Brussels. European Comission, 2014. Innovation Union Scoreboard, http://ec.europa.eu/enterprise/policies/innovation/files/ius/ius-2014_en.pdf Paul \& Dominique, 2002. "Economic Fundamentals of the Knowledge Society", Stanford University SIEPR Discussion Paper No.01-14 .

Kaynak, 2011. "Avrupa Birliği Yolunda Bilim Ve Teknoloji Bağlamında Türkiye'nin Ab-27 Ülkeleri Karşısındaki Mevcut Durumu", Bilgi Ekonomisi ve Yönetimi Dergisi, Cilt: VI Sayı: II

Umut, 2001. Assessment of possible effective strategies in the transition process to a knowledge-based economy: The case of Turkey, Middle East Technical University Industrial Engineering Department, Master's Thesis, Ankara.

George \& Yi-Hsing \& Zheng-Yi, 2008. "Competition policy for technological innovation in an era of knowledge-based economy." KnowledgeBased Systems, Vol. 21, pp. 826-832.

Gür, 2001. Assessment of possible effective strategies in the transition process to a knowledge-based economy: The case of Turkey , Middle East Technical University Industrial Engineering Department, Master's Thesis, Ankara.

Oğuz, 2005. "Bilgi Ekonomisi'nin Olası Mikro Ekonomik Etkilerinin Teorik Analizi", http://oguzkara.com/Bilgi\%20Ekonomisi'nin\%200lasi\%20Mikro\%20Ekonomik\%20Etkilerinin\%20Teorik\%20Analizi.pdf

Charles, 2000. The weightless society: Living in the new economy bubble. NewYork: Texere.

European Comission, 2001. The Impact of The E-Economy on European Enterprises: Economic Analysis and Policy Implications, Brussels.

European Comission, 2014. Innovation Union Scoreboard, http://ec.europa.eu/enterprise/policies/innovation/files/ius/ius-2014_en.pdf

European Patent Office, 2015. http://www.epo.org/about-us/annual-reports-statistics/annual-report/2014/statistics/patentapplications.html

Oytun, 2013. "Türkiye İ̧̧in 2010-2012 Dönemi Karşılaştırmalı Bilgi Ekonomisi Analizi", Eskişehir Osmangazi Üniversitesi İktisadi ve İdari Bilimler Fakültesi Dergisi,2013, 8(2), s. 115-139.

OECD, 1996. OECD, The Knowledge Based Economy, No. General Distribution OECD/GD(96)102, Paris.

OECD, 2015. http://www.oecd.org/pisa/keyfindings/pisa-2012-results-overview.pdf

Senem, 2011. "Analyzing of threshold effect in relationship with knowledge economy and growth", Hacettepe Üniversitesi, Sosyal Bilimler Enstitüsü / iktisat Anabilim Dalı, Ekonomi, Yüksek Lisans Tezi

Salduz, 2005. "Turkey's adaption to the transformation process of the European Union through competitive knowledge economy", Dokuz Eylül Üniversitesi, Social Science Institute, Master Thesis, İzmir

Susan, 2005. Re-imagining and rescripting the future of education: global knowledge economy discourses and the challenge to education systems, Comparative Education, 41 (2), 151-170.

Tuncay, 2008. "Knowledge economy and economic growth: An econometric analysis on Turkey (1980-2006)", Atatürk Üniversitesi / Sosyal Bilimler Enstitüsü / İktisat Anabilim Dalı, Ekonomi, Erzurum

Thomas A., 1997. Intellectual Capital: The new wealth of organization, Crown Business; 1st edition, San Francisco, CA

Kamil, 2007. "Teorik Çerçevesi ve Uygulama Örnekleriyle Dünyada ve Türkiye'deYazııım Endüstrisi”, Devlet Planlama Teşkilatı Müsteşarlığı, Planlama Uzmanlığı Tezi (yayımlanmamıs eser), Ankara.

World Bank, 2003. Lifelong Learning for a Global Knowledge Economy, Washington, DC

World Bank, 2004. "Turkey Knowledge Economy Assessment Study", http://www-

wds.worldbank.org/external/default/WDSContentServer/WDSP/IB/2007/04/06/000310607_20070406113501/Rendered/PDF/393650TROK nowledge0economy01PUBLIC1.pdf .

World Bank, 2010. Knowledge Assessment Methodology , http://www.worldbank.org/kam .

World Bank, 2015. http://data.worldbank.org/indicator/SE.SEC.NENR/countries

YASED International Investors Association,2014,

http://www.yased.org.tr/webportal/Turkish/Yayinlar/Pages/YASED2023HedefleriYolundaBIT.aspx 